\title{
Literature Study of Irrigation Management of Irrigation Modernization Based to Support the Productivity of Paddy
}

\author{
Muhamad Taufik ${ }^{1, *}$, Ruzardi $^{2}$ \\ ${ }^{1}$ Department of Civil Engineering, Universitas Muhammadiyah Purworejo, Purworejo, Indonesia \\ ${ }^{2}$ Department of Civil Engineering, Universitas Islam Indonesia, Yogyakarta, Indonesia
}

Received March 18, 2021; Revised September 7, 2021; Accepted September 24, 2021

\section{Cite This Paper in the following Citation Styles}

(a): [1] Muhamad Taufik, Ruzardi , "Literature Study of Irrigation Management of Irrigation Modernization Based to Support the Productivity of Paddy," Universal Journal of Agricultural Research, Vol. 9, No. 5, pp. 184 - 190, 2021. DOI: 10.13189/ujar.2021.090505.

(b): Muhamad Taufik, Ruzardi (2021). Literature Study of Irrigation Management of Irrigation Modernization Based to Support the Productivity of Paddy. Universal Journal of Agricultural Research, 9(5), 184 - 190. DOI: 10.13189/ujar.2021.090505.

Copyright $(2021$ by authors, all rights reserved. Authors agree that this article remains permanently open access under the terms of the Creative Commons Attribution License 4.0 International License

\begin{abstract}
The availability of irrigation water for agriculture is one of the determinant factors that affect production, so it is important and strategic to support the success of agricultural business, especially in an effort to increase food production and productivity to realize food security. The Indonesian government has already spent considerable funds on the agricultural irrigation sector, but paddy crop production has not increased, so innovative measures are needed in handling it. The use of seeds supports irrigation modernization, and quality fertilizer is the right step to increase paddy production. The irrigation modernization plan will also be directed to improve the efficiency and effectiveness of the utilization of irrigation management funds through the development and management of participatory irrigation. A literature study is needed to explore the research about the potential, problem, and solution that support the direction of irrigation management system renewal policy in paddy productivity improvement scheme. The result of the analysis based on a previous study on IKMI and IKSI showed that the low score of the indicator (IKMI $<60$ percent and IKSI $<55$ percent) is on Human Resources, which include human resources institution/manager and human resources community water users (P3A). The use of superior seeds and balanced organic fertilizer will affect paddy productivity by 18.18 percent. The establishment of UPIM will be beneficial in fostering the management of
\end{abstract}

modern irrigation systems and the use of quality seeds and fertilizers so that paddy productivity will be achieved.

Keywords Irrigation Modernization, Human Resources of Irrigation, The Productivity of Paddy

\section{Introduction}

The development of the agricultural sector, especially the subsector of food crops, has a significant and strategic role since the subsector of food crops has an essential role in supporting the lives of Indonesians, especially in the paddy farming sector [1]. With the population of Indonesia reaching $268,583,016$ people, it requires a considerable amount of paddy production. Paddy productivity in Indonesia production per year is 70.8 million tons, while the number of paddy imports: 1 million tons. The current large agricultural budget should increase paddy production in large quantities [2]. International Paddy Research Institute (IRRI) estimates that Indonesia will need 38 percent more paddy in 25 years, which means the average paddy yield is now 4.6 tons/ha, increasing to more than 6 tons/ha to fill the gap in domestic paddy needs [3].

Observing Indonesia's paddy crop productivity is still 
low compared to neighboring countries such as Vietnam. The government should continue to improve the quantity and quality of harvest in Indonesia. As results fulfilling the domestic food needs that are highly dependent on the agricultural sector. Paddy productivity in Vietnam per year reaches 45 million tons, while the number of paddy exports: 6.5 million tons. Vietnam is now the largest paddy producer in South East Asia and the world. Long before, Vietnam had learned from Indonesia, even had borrowed paddy in the New Order Era. Vietnam in 1989-1990 borrowed 100,000 tons of paddy to Indonesia. However, their paddy can currently offer a surplus of 5-6 million tons/year, one of the keys is they follow the agricultural system in Indonesia. Vietnam is now the world's largest paddy exporter and even beat Thailand.

The agricultural system that Vietnam emulates from Indonesia is an intensification, extension, and diversification program of agriculture. The average yield jumped from 4.2 tons/ha in 2000 to 5.6 tons/ha at that time [4]. Indonesia's paddy productivity is inferior compared to Vietnam. From the Ministry of Agriculture shows that Indonesia's paddy productivity in 2010-2014 only reached 5.08 tons/ha, but still above the world paddy productivity of 4.47 tons/ha. Meanwhile, Vietnam's paddy productivity is 6.57 tons/Ha. Although paddy farming in Vietnam is not as extensive as Indonesia, they have higher productivity than in Indonesia. At the same time, Australia is the world's paddy producer with the highest paddy production productivity, which reaches 10 tons/ha. Egypt, with a productivity of 9.5 tons/ha, the United States with productivity reached 8.18 tons/ha, and South Korea 6.92 tons/ha [5].

The contribution of irrigation infrastructure and facilities is significant to food security. So far, it is quite large, i.e., as much as 84 percent of national paddy production is sourced from irrigation areas [6]. Therefore, to increase agricultural production and improving the quality of seeds, fertilization, eradication of pests and crop diseases, it is also necessary of pay attention to irrigation. The need for factor $\mathrm{K}$ (coefficient of flow) to fulfil irrigation needs in paddy fields is still too large due to the high level of seepage. Waterloss along the channel is significant enough caused by the differences in elevation during drainage [7]. Water utilization efforts through irrigation require a good management system so that water utilization can be implemented effectively and efficiently.

The Government of Indonesia is encouraged to improve the irrigation development and management system into a participatory irrigation system that is more effective, efficient, and sustainable or called by the term irrigation modernization, which focuses more on improving irrigation efficiency and service level [8]. Irrigation modernization is an effort to realize a participatory irrigation management system oriented to the fulfilment of the level of irrigation services effectively, efficiently, and sustainably to support food and water security through the method of 5 pillars of modern irrigation, namely: improving the reliability of water supply, infrastructure, irrigation management, management institutions, and human resources [9]. Many countries, such as Malaysia, have followed the decision to modernize irrigation carried out the construction of dams, pumping stations, the development of canal inspection roads and crop transportation roads, and improved efficiency [10].

Vietnam established the Irrigation Modernization Frame (IMF) in the Red River Delta (RRD), which is service-oriented management to create irrigation exploitation efficiency [11]. Irrigation modernization is different from rehabilitation which only emphasizes the physical aspect. In addition to highlighting the physical aspect, the concept of irrigation modernization also made improvements to the institutional aspects of management and human resources to provide services to farmers [12]. Indonesia has more problems ranging from human resources, technology - unsophisticated technology, attitudes and behaviors of farmers who are challenging to change in farming activities, such as compliance with water turn, water use, planting pattern system, and others [13].

In addition to the 5 pillars of modern irrigation, the selection of seeds and fertilizers with good quality and appropriate land conditions, significantly affects paddy productivity. Seed selection and fertilization are the essential factors in the effort to increase production. So far, farmers rely heavily on artificial fertilizers/chemicals (inorganic) and tend not to pay attention to land conditions that result in the imbalance of soil nutrients [14]. The use of several types of fertilizer and the difference in planting age of the suitable seedlings is very influential in increasing paddy production [15].

\section{Literature Review}

\subsection{Irrigation Modernization}

Irrigation, as one of the supporting components of successful agricultural development, has a significant role in paddy productivity. Government budget constraints resulted in limited operating and maintenance funds, resulting in many technical conditions of irrigation networks, both physical and functional, being disrupted. This situation can be overcome through good cooperation between the government and the community, especially farmers who directly impact [16].

Ristiyana et al. [17] conducted a study entitled implementation of irrigation management based on 5 pillars of irrigation modernization in Batang Anai West Sumatra. This study focused on the management of irrigation based on 5 pillars due to the problems such as agricultural-related water utilization aims to meet food needs that have not been maximized, policies and 
management of irrigation channels are deficient, budget constraints owned by the government, which then resulted in limited funds for operation and maintenance, so that the impact of many technical conditions of irrigation networks, both physical and functional become disrupted [18]. Therefore, irrigation modernization becomes an effort to realize a participatory irrigation management system oriented to fulfil the level of irrigation services effectively, efficiently, and sustainably to support food and water security through improving the reliability of water supply, infrastructure, irrigation management, management institutions, and human resources [9].

Bastin Yungga Angguniko and Susi Hidayah [8], in their research on the Design of Modern Irrigation Management Unit in Indonesia, discussed the weak efforts to manage irrigation networks which caused as much as 3.3 million hectares of network area or as much as 52 percent that was in bad condition in 2014. The establishment of irrigation management units in Indonesia is a mandate stated in the National Medium Term Development Plan 2015-2019. An irrigation management unit under a supervision is a very appropriate step to improve the performance of network conditions. The purpose of this research is to obtain the design of a Modern Irrigation Management Unit (UPIM), which includes irrigation Operations and Maintenance services program, UPIM organizational structure and its relationship with other institutions, human resources needs (HR), supporting infrastructure, and budgeting system. The results showed that based on the results of an audit of irrigation management practices in five areas, both through self-managed mechanisms and management tasks, nine key factors could support management's success.

\subsection{The Improvement of Facility and Infrastructure of Irrigation}

According to Mustabsir. B [19] explained in his research titled Evaluation of Availability of Agricultural Facilities and Infrastructure in Supporting Food Security in Anreapi Subdistrict, Polewali Mandar Regency. Food security problems in the sub-district where the area is supposed to be food self-sufficiency, but lately, there has been a decrease in productivity, the hypothesis delivered by Mustabsir is a miss management of agricultural lands to the weak availability of various existing production facilities. Therefore, referring to the condition of the need for modification of agriculture and the provision of facilities and infrastructure, based on the results of the analysis, the availability of agricultural facilities and infrastructure in supporting food security in the Anreapi sub-district has been running quite well, but still constrained by some things related to the lack of human resources both in number and quality and still poor irrigation channels as well as lack of other agricultural infrastructure facilities.

Yulasni Astri et al. [20] conducted a study on Performance Assessment of Irrigation District Facilities and Infrastructure Muara Jalai Village Kampar Regency. This research focuses the performance of irrigation area facilities and infrastructure, aimed to obtain assessment and information on the technical condition of network performance and operation and maintenance in one unit of an irrigation area in the Muara Jalai Kampar Regency. This study collection data, two set of, data collected by primary data (observation and direct observation in the field) and secondary (air temperature data, solar illumination data, air humidity data, wind speed data, network maps, and building schemes) in Muara Jalai-calculating irrigation water needs, using the modified Penman method, calculating the availability of irrigation water by comparing the area of Bingkuang Lake watershed with the location of Muara Jalai watershed. Field survey activities for the search of the leading network (primary channel) in DI Muara Jalai. Analysis of primary and secondary data using methods referring to Regulation of the Minister of Public Works No. 12/PRT/M/2015 concerning Exploitation and Maintenance of Irrigation Networks. They assess the performance of irrigation facilities and infrastructures that are reviewed technically and follow other laws or regulations related to such activities.

\subsection{Improvement of the Irrigation Management System}

Study of The Effectiveness and Efficiency of Irrigation Network on Water Needs in Paddy Plants (Case Study of Irrigation Kaiti Samo District Rambah Rokan Hulu), [16]. This research is based on the need to support the provision of national foodstuffs so that water availability on the land will be met even though the ground is far from surface water sources. It is inseparable from irrigation techniques that provide water with excellent quality, proper space, and time effectively and economically. The contribution of infrastructure and irrigation facilities is significant for food security. So far, it is quite large, such as 84 percent of national paddy production is sourced from irrigation areas. Therefore, to increase agricultural production and improve the quality of seeds, fertilization, eradication of pests and crop diseases, it is also necessary to pay attention to irrigation. Water utilization efforts through irrigation require a sound management system so that water utilization can be implemented effectively and efficiently.

\subsection{Strengthening Irrigation Management Institutions}

Sigit Supadmo Arif and Dede Sulaeman [21], in training on Institutional Development and Empowerment of Irrigation Society, explained that irrigation had become 
an integral part of human life, including Indonesian people with a tropical climate. The problems that arise in irrigation management will be more complex and not only related to infrastructure development itself since the infrastructure is only one part of the management of the irrigation system as a whole. The differences in perception need to be recognized to help in understanding why different individuals and societies respond to the environment in very different ways. The Clean Irrigation Movement comes into the context of the "re-actualization and revitalization of local cultural values that have faded." The existence of 4 typologies of farmer participation activities in implementing GIB in secondary and primary irrigation channels. The use of almost human empowerment irrigation factors can be done in the future because essentially, man is the perfect creature created by God on earth [21].

\subsection{Empowerment of Irrigation Management Human Resources}

Sutrisno, D and Rahdriawan, M. [22], in a study about Community Empowerment and Improvement Efforts in the Management of Mendut Irrigation Network Semarang district revealed, the results which are then analyzed to find out the true condition of community empowerment in the management of Mendut irrigation network. The results of this study were found several things such as that community empowerment in the management of mendut irrigation network has not been running because there are still many elements of community empowerment that have not been running, such as irrigation dues that have not been running, the level of knowledge and ability of the community is still lacking. The need for some improvement efforts that can be done such as strengthening efforts, possibility, protection, dispossession, maintenance, coaching, mentoring, and training.

\subsection{The Effect of Seeds and Fertilization on Paddy Productivity}

I Kadek Wahyu Widiatmaka et al. [15] conducted a study titled The Influence of Several Types of Fertilizers and Seeds on Paddy Growth and Yield (Oryza sativa L.). Results indicated that seed selection and fertilization are essential factors in efforts to increase production. The effort needs to be made to re-improve soil fertility, is using by chemicals fertilizing in a balanced manner and suitable for the needs of plants. This effort will not necessarily restore the fertility rate of the land if it is not accompanied by organic matter in green fertilizer or compost. The purpose of this study is to determine the type or combination of fertilizer and the best seed age that can be used in the growth and yield of paddy plants to the maximum.

K. Agus Wirawan et al. [23] conducted a study entitled
Paddy Productivity Analysis in Badung Bali Province. The development of agricultural production in the Badung Regency takes precedence over increasing productivity compared to increasing land area. The local government calculates paddy production using a method known as 'tile.' Tile is essential because it is used as official statistical data to calculate production, productivity, forward prediction. Handling of production factors in planting, the use of fertilizers, chemical products, pest control, and lack of knowledge about tile, thus making the productivity of paddy farmers does not increase significantly. This study aims to examine and analyze the magnitude of the gap or the difference between the estimated production of tile products and the real production of farmers on selected plots/paddy fields.

\section{Research Method}

The research type used is descriptive research. The research method used is a literature study. This research is conducted by reading, collecting, recording, studying books, studying relevant previous research through various literature, books, notes, magazines, other references, and relevant previous research results to obtain answers and theoretical foundations on the problems to be researched. The reference materials obtained to support the discussion of this literature study are:

\subsection{Irrigation Modernization}

Covering five pillars as an effort to realize participative irrigation management system oriented in the fulfilment of irrigation service level effectively, efficient and sustainable in the term of supporting food and water security through: (i) improving the reliability of irrigation water supply, (ii) improving irrigation facilities and infrastructure, (iii) improving irrigation management systems, (iv) strengthening irrigation management institutions, and (v) empowering irrigation management human resources.

\subsection{Irrigation Modernization Readiness Index (IMRI) and Irrigation System Performance Index (ISPI)}

In general, IMRI and ISPI include physical facility, support, and human resources. From this value obtained an overview of the management conditions of existing irrigation systems so that it can be as a basis in consideration of existing solutions.

\subsection{The Effect of Selecting Seeds and Fertilizers in Increasing Paddy Production}

Previous research literature about seedlings and fertilizers showed paddy production is greater than 
existing products so that it can be a comparison and reformer in the implementation of agriculture.

\section{Result and Discussion}

The research about irrigation modernization has been conducted by Suci Ristiyana et al. [17] to develop a policy of irrigation modernization in Batang Anai, West Sumatra. IMRI data processing (Irrigation Modernization Readiness Index) conducted using Excel obtained results from the five pillars of irrigation modernization Batang Anai Irrigation Region presented in Table 1. Through the calculation of IMRI value, it can be noticed that two pillars of irrigation modernization are high and adequate condition value, such as Water Availability and Irrigation infrastructure. At the same time, the 3 pillars of irrigation modernization have a value of $<60$, i.e., management systems, government institutions, and human resources. The improvement takes 1-2 years to meet adequate predicate for irrigation modernization. Modernization carried out and applied in this irrigation area will be planned and prepared input policies as a reference pattern of achieving irrigation modernization in the future.

Table 1. The value of IMRI of Batang Anai Irrigation Area

\begin{tabular}{ccccc}
\hline $\begin{array}{c}\text { Pilar } \\
\text { Irrigation }\end{array}$ & $\begin{array}{c}\text { Weight } \\
(\%)\end{array}$ & $\begin{array}{c}\text { Condition } \\
(\%)\end{array}$ & Category & $\begin{array}{c}\text { IMRI } \\
(\%)\end{array}$ \\
\hline $\begin{array}{c}\text { The } \\
\text { availability } \\
\text { of water }\end{array}$ & 20 & 80 & Adequate & 16,0 \\
$\begin{array}{c}\text { Irrigation } \\
\text { infrastructure } \\
\text { Management } \\
\text { system }\end{array}$ & 25 & 90 & Adequate & 22,5 \\
$\begin{array}{c}\text { Manager } \\
\text { institution } \\
\text { Human } \\
\text { resources }\end{array}$ & 20 & 41 & Less & 8,2 \\
\hline & 15 & 53 & Sufficient & 10,5 \\
\hline
\end{tabular}

Source: Ristiyana et al. [17]

Yulasni Astri et al. [20] in her research entitled Performance Assessment of Irrigation District Facilities and Infrastructure Muara Jalai Kampar Regency. The problem in this study is to assess the performance of irrigation area service levels that are still not optimal in Muara Jalai irrigation area. This research aims to assess the facilities and infrastructure of technical conditions of irrigation network performance. Operation and maintenance consist of routine, special, and periodic maintenance. The method of analysis of performance assessment of maintenance operations in Muara Jalai refers to Regulation of the Minister of Public Works No. 12/PRT/M/2015 concerning Exploitation and Maintenance of Irrigation Networks.
Table 2. Index Value of Irrigation System Performance in Muara Jalai

\begin{tabular}{ccccc}
\hline $\begin{array}{c}\text { Performance } \\
\text { aspect }\end{array}$ & $\begin{array}{c}\text { Weight } \\
(\mathbf{\%})\end{array}$ & $\begin{array}{c}\text { Condition } \\
(\mathbf{\%})\end{array}$ & Category & $\begin{array}{c}\text { ISPI } \\
(\mathbf{\%})\end{array}$ \\
\hline $\begin{array}{c}\text { Physical } \\
\text { Infrastructure }\end{array}$ & 45 & 69,90 & Good & 31,44 \\
$\begin{array}{c}\text { Productivity of } \\
\text { plant }\end{array}$ & 15 & 76,74 & Good & 11,51 \\
$\begin{array}{c}\text { Supported } \\
\text { Facility }\end{array}$ & 10 & 55,00 & Less & 5,50 \\
$\begin{array}{c}\text { Personnel } \\
\text { organization }\end{array}$ & 15 & 47,33 & Bad & 7,10 \\
$\begin{array}{c}\text { Documentation } \\
\text { Farmer }\end{array}$ & 5 & 50,00 & Less & 2,50 \\
association & 10 & 56,00 & Less & 5,60 \\
$\begin{array}{c}\text { Water user } \\
\text { (GP3A/IP3A) }\end{array}$ & 100 & & & \\
\hline
\end{tabular}

Source: Astri et al. [20] and data processing

Evaluation is conducted every year with the assessment of irrigation system performance index as follow:

(a) 80 -100: very good performance

(b) 70 - 79: good performance

(c) 55 - 69: less performance and need to be paid attention

(d) <5: bad performance and need to be paid attention

From Table 2 it can be explained that the results of the analysis on the Value of Irrigation System Performance Index for Muara Jalai Irrigation Area, components including the category of both physical infrastructure and planting productivity. The other 3 components include the less category and the Personnel Organization component falls into the ugly category. The total Irrigation System Performance Index value falls into the category of less good and needs attention.

Table 3. The Value of Irrigation System Performance Index of Van Der Wick Irrigation Area

\begin{tabular}{ccccc}
\hline $\begin{array}{c}\text { Performance } \\
\text { Aspect }\end{array}$ & $\begin{array}{c}\text { Weight } \\
(\%)\end{array}$ & $\begin{array}{c}\text { Condition } \\
(\mathbf{\%})\end{array}$ & Category & $\begin{array}{c}\text { ISPI } \\
\mathbf{( \% )}\end{array}$ \\
\hline $\begin{array}{c}\text { Physical } \\
\text { Infrastructure } \\
\text { Productivity of } \\
\text { plant }\end{array}$ & 45 & 77,40 & Good & 34,83 \\
$\begin{array}{c}\text { Supported } \\
\text { Facility } \\
\text { Personnel } \\
\text { organization }\end{array}$ & 15 & 96,60 & $\begin{array}{c}\text { Very } \\
\text { good }\end{array}$ & 14,49 \\
$\begin{array}{c}\text { Documentation } \\
\text { Farmer }\end{array}$ & 5 & 62,60 & Less & 6,26 \\
$\begin{array}{c}\text { association } \\
\text { Water user } \\
\text { (GP3A/IP3A) }\end{array}$ & 10 & 76,13 & Good & 11,42 \\
\hline & 10,00 & Good & 3,60 \\
\hline
\end{tabular}

Source: Nugroho et al. [24] and data processing

Moh Nugroho also researched Irrigation System Performance Index, Ruzardi and Lalu Makrup, to evaluate irrigation network management and assess the performance of irrigation networks using the fuzzy set 
theory method and method based on PUPR Candy No. 12/PRT/M/2015 on Guidelines for Exploitation and Maintenance of Irrigation Networks. From the calculation results, the assessment of the performance of irrigation systems van Der Wijck Irrigation Area with the manual method of the hall and fuzzy method is averaged, as shown in Table 3.

From Table 3, it can be observed that from 6 aspects of performance, planting productivity has the highest value of 96.60 percent with a very good category, then 3 aspects of performance with good categories and there are 2 aspects of performance that have less value, such as the aspects of supporting facilities performance and the Association of Water User Farmers (GP3A/IP3A).

Based on some of these studies, it can be categorized that the value of underperformed aspects is in the management system, management organizations and associations of water user farmers (GP3A/IP3A). Therefore, it needs special handling of the problem. Research conducted by Bastin Yungga Angguniko and Susi Hidayah [8] about the Design of Modern Irrigation Management Unit (MIMU) can be conducted in Indonesia with the hope of resolving human resource problems. MIMU is a work unit responsible for the operation and maintenance of irrigation in an Irrigation Area with participatory, needs-based, effective, efficient, and sustainable principles that ensure a better level of service to water-use farmers. The concept of MIMU implementation should be adjusted to the applicable irrigation policy suitable for the situation and conditions of the local wisdom of the local community. The population of this research includes 8 Irrigation Districts in Indonesia that will be modernized, such as irrigation area of Colo (cross Karanganyar, Sragen, and Ngawi), Wadaslintang (Kebumen and Purworejo Districts), Rentang (Cirebon, Indramayu and Majalengka), Tajum (Banyumas Regency), and Cisadane Empang (Bogor Regency, Bogor City, and Depok City). The determination of the number of sampling is done based on the purposive sampling method. The purposive sample is the area that will be implemented irrigation modernization suitable for the information received from the Irrigation Modernization Team and irrigation areas representing typology. The provision of irrigation water for agriculture is one of the main concerns and irrigation management needs to be done in an integrated manner under one participatory management unit. In this study, the unit was called Modern Irrigation Management Unit (UPIM). Based on the results of an audit of irrigation management practices in five irrigation areas, both through self-managed mechanisms and management tasks, nine key factors were found that could support the success of irrigation management. The management implementation can be done independently or manageably, namely bestowing authority on provincial and district governments. In addition, MIMU needs support in the form of legalization of institutions that can be regulated through a decree of the minister/governor/regent and must be equipped with detailed implementation guidelines and understood by all stakeholders both at the central and regional level.

Supporting factors for the increase of paddy production, besides the modernization of irrigation through the formation of MIMU, are also carried out with other efforts, such as selecting superior seeds and the use of balanced organic fertilizer. This case can be shown in the research of I Kadek Wahyu Widiatmaka et al. [15], about the Influence of Several Types of Fertilizers and Seeds on Paddy Growth and Yield (Oryza sativa L.). The result showed that the interaction of fertilization and breeding age had a noticeable influence on panicles length and an evident influence on the harvest index. A single fertilizer (fertilizer containing only one type of nutrients only) is very significant to the height of plants, the number of leaves, the maximum number of samples and productive, broad leaves, the number of panicles per clump, dry crops and dry ovens per clump, wet weight and dry straw oven. In comparison, the treatment of seedlings has a real effect on the height of plants, the number of leaves, the maximum number of saplings, the amount of grain per panicle, the length of panicles and the weight of grain per panicle. Paddy production of 6.58 tons/ha was obtained from organic and chemical fertilization with seed life of 7 days after sprouting.

Similar research conducted by Agus Wirawan et al. [23] under the title Paddy Productivity Analysis in Badung Bali province, showed that from 41 samples of paddy farmers, there is an estimated difference in production produced by paddy tiles to the real results of farmers. The average estimated tile value is $81.66 \mathrm{~kg} / \mathrm{are}$ while the real production is $69.10 \mathrm{~kg} / \mathrm{are}$. There is a difference of 12.56 $\mathrm{kg}$ /are or about 1.26 tons per hectare or $18.18 \%$ compared to actual production.

\section{Conclusions}

To improve irrigation performance effectively, efficiently, and sustainably, it is necessary to improve irrigation thoroughly by implementing 5 pillars of irrigation modernization, such as: improving the reliability of irrigation water supply, improvement of irrigation facilities and infrastructure, improvement of irrigation management systems, strengthening of irrigation management institutions, empowerment of human resources of irrigation managers.

The successful key of irrigation modernization is the empowerment of human resources. The mindset of irrigation officers should be changed from traditional to modern irrigation, whose implementation changes from supply service-oriented management to demand-oriented management. 
From the analysis of Index readiness of Irrigation Modernization (IRIM) and Index of Irrigation System Performance (IISP), low value or $<60$ that includes human resources managers institutions and human resources irrigation beneficiaries, namely P3A. Therefore, it is necessary to establish MIMU (Modern Irrigation Management Unit) as a container for irrigation management carried out in an integrated manner under one participatory management unit. The selection factor of superior seeds and balanced organic fertilizer can increase paddy productivity, ranging from 18.18 percent.

\section{REFERENCES}

[1] Haris, W. A., et al. (2017). Analisis Peranan Subsektor Tanaman Pangan terhadap Perekonomian Jawa Barat. Journal of Regional and Rural Development Planning.

[2] Ismail, N. W. et al (2009). The Effect of ASEAN Economic Integration on Foreign Direct Investment. Journal of Economic Integration, Vol. 24, No. 3 (September 2009).

[3] Baldwin, K. et al. (2012). "Southeast Asia’s Paddy Surplus", A Report from the Economic Research Service, United States Department of Agriculture.

[4] Wailes, E. J. dan Chavez, E. C. 2012. "ASEAN and Global Paddy Situation and Outlook", ADB Sustainable Development Working Paper Series No. 22, Asian Development Bank, Mandaluyong City, 2012, h. 10

[5] Kementerian Pertanian. (2016). Outlook Komoditas Pertanian Sub Sektor Tanaman Pangan (Padi). Pusat Data dan Sistem Informasi Pertanian Kementerian Pertanian. Jakarta.

[6] Purwaningsih, Y. (2008). Ketahanan Pangan: Situasi, Permasalahan, Kebijakan, dan Pemberdayaan Masyarakat. Jurnal Ekonomi Pembangunan Vol. 9, No. 1, Juni 2008.

[7] Taufik, M., \& Setiawan, A. (2018). Analisis Efisiensi Irigasi Pada Petak Tersier Dengan Metode Drum. Proceeding of The 7th University Research Colloquium 2018: Bidang Teknik dan Rekayasa (pp. 6-14). Surakarta: STIKES PKU Muhammadiyah Surakarta.

[8] Angguniko, B. Y., et al. (2017). Rancangan Unit Pengelola Irigasi Modern di Indonesia. Jurnal Irigasi Vol. 12, No 1, Mei 2017.

[9] Arif, S. S., et al. (2014). Pokok - Pokok Modernisasi Irigasi Indonesia. Dirjend SDA Kementrian PUPR, Jakarta.

[10] Martief, M. M., \& Krisbandono, A. (2015). Modernisasi, Peningkatan Jaringan, atau Rehabilitasi Irigasi. Badan Penelitian dan Pengembangan, Kementerian Pekerjaan Umum dan Perumahan Rakyat. Jakarta, Indonesia.

[11] Nam, V. H. (2016). International Conference on the
Mekong, Salween and Red Rivers: Sharing Knowledge and Perspectives Across Borders (hlm. 429-455). Chulalongkorn University.

[12] Hakim, A., Suriadi, A., \& Masruri. (2012). Tingkat kesiapan masyarakat petani terhadap rencana modernisasi irigasi (studi kasus di Daerah Irigasi Barugbug, Jawa Barat). Jurnal Sosial Ekonomi Pekerjaan Umum, 4(2), 67-78.

[13] Nuryanti \& Swastika (2011). Peran Kelompok Tani dalam Penerapan Teknologi Pertanian. Jurnal Forum Penelitian Agro Ekonomi.

[14] Wegari, A., \& Amin, M. (2020). Early growth response of Hararghe Coffee selections to soil moisture deficit at seedling stage at Mechara, Eastern Ethiopia. Universal Journal of Agricultural Research, 8(6), 223-232. DOI: 10.13189/ujar.2020.080603.

[15] Widiatmika, I. K. W. et al (2017). Pengaruh Beberapa Jenis Pupuk dan Umur Bibit terhadap Pertumbuhan dan Hasil Tanaman Padi (Oryza sativa L.). Jurnal AGROTROP.

[16] Rismanto, et al. (2013). Kajian Peran Serta Petani dalam Operasi dan Pemeliharaan Infrastruktur Jaringan Irigasi dengan Pendekatan Theory of Planed behaviour. Jurnal Sosioteknologi Edisi 30 Tahun 12, Desember 2013.

[17] Ristiyana, S., et al. (2020). Implementasi Pengelolaan Irigasi Berbasis Lima Pilar Modernisasi Irigasi di Batang Anai Sumatra Barat. Jurnal Ilmu Rekayasa Pertanian dan Biosistem, Vol. 8, No. 2, September 2020, Unram.

[18] Nurali Chorshanbiev Esanpulatovich, et al (2021). Analysis of an Experiment Carried Out on the Lines and Varieties of Fine Fiber Cotton. Universal Journal of Agricultural Research, 9(1), 6 - 12. DOI: 10.13189/ujar.2021.090102.

[19] Mustbasir. (2017). Evaluasi Ketersediaan Sarana dan Prasarana Pertanian dalam Mendukung Ketahanan Pangan di Kecamatan Anreapi Kabupaten Polewali Mandar. UIN Alauddin. Makassar.

[20] Astri, Y. et al. (2018). Penilaian Kinerja Sarana dan Prasarana Daerah Irigasi (DI) Desa Muara Jalai Kabupaten Kampar. Jurnal Jom FTEKNIK Volume 5 Edisi 1, Juni 2018.

[21] Arif, S.S., \& Sulaeman, Dede. (2014). Pengembangan Institusi dan Pemberdayaan Masyarakat Irigasi dalam Bahan Pelatihan "Peningkatan Kemampuan Perencanaan Teknis Irigasi, Air Baku, dan Air Tanah”. Dirjend SDA Kementrian PUPR, Jakarta.

[22] Sutrisno, D dan Rahdriawan, M. (2005). Pemberdayaan Masyarakat Dalam Pengelolaan Jaringan Irigasi Mendut Kabupaten Semarang. Jurnal Tata Loka, 7 (3). ISSN 0852-7458.

[23] Wirawan, K. G. et al. (2014). Analisis Produktivitas Tanaman Padi di Kabupaten Badung Provinsi Bali. Jurnal Manajemen Agribisnis Vol. 2, No. 1, Mei 2014.

[24] Nugroho, M., et al. (2018). Evaluasi Kinerja Sistem Irigasi Daerah Irigasi Van Der Wijk dengan Menggunakan Fuzzy Set Theory. UII. Yogyakarta. 